\title{
Methods and resources needed in treating SARS-CoV-2 in wastewater
}

\author{
Gilbert D. Bernardino Jr¹, Kim Oliver R. Domondon², Judith A. Layao ${ }^{1}$, Judith Odanee G. Magwilang ${ }^{1}$, Howard M. Eckman ${ }^{3}$
}

\section{AFFILIATION}

1 College of Nursing, University of the Cordilleras, Baguio City, Philippines 2 College of Engineering and Architecture, University of the Cordilleras, Baguio City, Philippines

3 School of Nursing, Saint Louis University, Baguio City, Philippines

CORRESPONDENCE TO

Gilbert Jr Bernardino. College of Nursing, University of the Cordilleras,
Governor Pack Road, Baguio City, 2600, Philippines. E-mail: gdbernardino@uc-bcf.edu.ph ORCID ID: https://orcid.org/0000-00028272-8518

KEYWORDS

SARS-CoV-2, wastewater, COVID-19

Received: 12 January 2021, Accepted: 15 January 2021

https://doi.org/10.18332/popmed/132470

Popul. Med. 2021;3(February):5

treatment facilities can also be more expensive to construct and operate ${ }^{7}$, thereby making decentralized wastewater treatment facilities in the context of developing countries more feasible.

\section{Point-of-use devices for virus decontamination.} Adelodun et al. ${ }^{6}$ recommend the use of inexpensive approaches such as the use of filters like iron-oxide bio-sand, zero-valent iron, nanocellulose-based filters and gravitybased ultrafilters, and the use of oxidants like chlorine, as well as ozonation and UV irradiation. The use of flocculants and coagulants that are stored in sachets, moreover, have helped to reduce pathogenic organisms that cause diarrhea in Kenya, Guatemala, and Vietnam ${ }^{8}$. Coagulation and flocculation, however, are not standalone methods but must be used in conjunction with other approaches.

3. Cultivation of microalgae. Wastewater disinfection using cultivated microalgae, specifically the use of Galdieria sulphuraria has been proven to remove high rates of coliphages, noroviruses and enteroviruses ${ }^{9}$. Viruses in wastewater can be removed when they are adsorbed onto the biomass of microalgae, followed by the process of sedimentation ${ }^{9}$. Nwoba et al. ${ }^{10}$ in addition, asserted that bioproducts that can be obtained from wastewater-grown microalgal biomass may include animal feed, biofuels and biofertilizers. These bioproducts, derived from the innovative and sustainable cultivation of microalgae, can then help to boost the economic status of individuals in impoverished communities.

Examining wastewater for fragments of the SARSCoV-2 virus provides health and sanitation authorities with the advantage of knowing whether pandemics or outbreaks are likely to occur. Point-of-use devices for virus decontamination are widely available but they are not without risks and disadvantages. Given the present magnitude of the COVID-19 pandemic among developing 
countries, it is important that health authorities consider cost-effective mechanisms on how to prevent the further spread of the virus by innovating existing approaches on the treatment of wastewater, in addition to the implementation of physical distancing and community lockdowns.

\section{REFERENCES}

1. Centers for Disease Control and Prevention. Information for Sanitation and Wastewater Workers on COVID-19. https://www.cdc.gov/coronavirus/2019-ncov/community/ sanitation-wastewater-workers.html. Updated May 28, 2020. Accessed August 18, 2020.

2. Mallapaty S. How sewage could reveal true scale of coronavirus outbreak. Nature. 2020;580(7802):176-177. doi:10.1038/d41586-020-00973-x

3. Daughton CG. Wastewater surveillance for populationwide Covid-19: The present and future. Sci Total Environ. 2020;736:139631. doi:10.1016/j.scitotenv.2020.139631

4. Sims N, Kasprzyk-Hordern B. Future perspectives of wastewater-based epidemiology: Monitoring infectious disease spread and resistance to the community level. Environ Int. 2020;139:105689. doi:10.1016/j.envint.2020.105689

5. Lodder W, de Roda Husman AM. SARS-CoV-2 in wastewater: potential health risk, but also data source. Lancet Gastroenterol Hepatol. 2020;5(6):533-534. doi:10.1016/S2468-1253(20)30087-X

6. Adelodun B, Ajibade FO, Ibrahim RG, Bakare HO, Choi KS. Snowballing transmission of COVID-19 (SARS-CoV-2) through wastewater: Any sustainable preventive measures to curtail the scourge in low-income countries?. Sci Total Environ. 2020;742:140680. doi:10.1016/j.scitotenv.2020.140680

7. Chirisa I, Bandauko E, Matamanda A, Mandisvika G. Decentralized domestic wastewater systems in developing countries: the case study of Harare (Zimbabwe). Appl Water Sci. 2017;7(3):1069-1078. doi:10.1007/s13201-016-0377-4

8. Pooi CK, Ng HY. Review of low-cost point-of-use water treatment systems for developing communities. NPJ Clean Water. 2018;1:1-8. doi:10.1038/s41545-018-0011-0

9. Bhatt A, Arora P, Prajapati SK. Occurrence, fates and potential treatment approaches for removal of viruses from wastewater: A review with emphasis on SARS-CoV-2. J Environ Chem Eng. 2020;8(5):1-11. doi:10.1016/j.jece.2020.104429

10. Nwoba EG, Vadiveloo A, Ogbonna CN, Ubi BE, Ogbonna JC, Moheimani NR. Algal Cultivation for Treating Wastewater in African Developing Countries: A Review. Clean: soil, air, water. 2020;48(3):1-14. doi:10.1002/clen.202000052

\section{CONFLICTS OF INTEREST}

The authors have completed and submitted the ICMJE Form for Disclosure of Potential Conflicts of Interest and none was reported.
PROVENANCE AND PEER REVIEW

Not commissioned; internally peer reviewed.

FUNDING

There was no source of funding for this research. 